Potravinarstvo Slovak Journal of Food Sciences

vol. 15, 2021, p. 732-740

https://doi.org/10.5219/1679

Received: 37 July 2021. Accepted: 25 August 2021.

Available online: 28 September 2021 at www.potravinarstvo.com

(C) 2021 Potravinarstvo Slovak Journal of Food Sciences, License: CC BY 4.0

ISSN 1337-0960 (online)

\title{
CHANGES IN ORGANOLEPTIC, MICROBIOLOGICAL AND BIOCHEMICAL PROPERTIES OF KEFIR WITH IODINE ADDITION DURING THE STORAGE
}

\author{
Diana Dalevska, Oleg Pokotylo, Mykola Kukhtyn, Nataliia Kopchak, Volodymyr Salata, \\ Yulia Horiuk, Tetyana Uglyar
}

\begin{abstract}
Iodine is a vital trace element that must be constantly and daily supplied with food to the organism. Currently, the amount of food that can provide the organism with the required amount of iodine is insufficient. The purpose of the study was to investigate changes in organoleptic, microbiological, and biochemical parameters of kefir made with the addition of iodine during its refrigeration storage. It was found that during the storage of samples of kefir with iodine there is a slowdown in the reproduction of lactic acid bacteria, compared with the control sample. In particular, the number of lactic acid bacteria during the first two days of storage increased 1.3 times in the experimental sample and 1.5 times in the control sample of kefir. After 12 days of storage, the number of lactobacilli in the test sample of kefir increased 2.5 times, and in the control 3.2 times, compared with the amount in fresh kefir. Similar patterns were observed in determining the development of yeast. In particular, the reproduction rate of yeast in the control sample of kefir was, on average, 1.3 times faster ( $8-12$ days), compared with yeast in the experimental sample. It was also found that during the 12-day storage period at a temperature of $+6{ }^{\circ} \mathrm{C}$, the titrated acidity in kefir with iodine increased 1.4 times, and in the control 1.6 times and was $130.5^{\circ} \mathrm{T}$ and $154.1^{\circ} \mathrm{T}$, respectively. At such acidity values, the test sample of kefir still met the requirements of the standard, and the control was $24.1^{\circ} \mathrm{T}$ higher. In this case, kefir containing iodide had better organoleptic characteristics during 12 days of storage. Produced kefir with the addition of iodine can be considered a functional product to provide the population with sufficient iodine.
\end{abstract}

Keywords: kefir; iodide concentrate; titrated acidity; lactic acid microorganisms; storage temperature

\section{INTRODUCTION}

Iodine is a vital trace element that must enter the organism constantly and daily with food (Hynes, et al., 2013; Abel, et al., 2017). Iodine is the most important component in the formation of thyroid hormones: thyroxine and triiodothyronine, which in turn regulate metabolism and several vital functions of the organism (Kopchak, et al., 2018a). At insignificant earnings of iodine in an organism, adaptive processes directed on effective use of this element work are triggered. However, prolonged lack of iodine leads to iodine deficiency diseases, accompanied by various pathologies (Abel, et al., 2017; Kopchak and Pokotylo, 2018b). The problem of iodine deficiency is especially relevant for regions that are far from the sea and have mountainous relief (Ryzhkova, et al., 2017). Ukraine is an iodine-deficient country with varying degrees of deficit, depending on the region.

The main natural source of iodine is seafood. However, according to research (Nerhus, et al., 2018), the iodine content in marine fish ranged significantly from $18 \mu \mathrm{g} / 100 \mathrm{~g}$ of wet mass (Atlantic halibut) to $1210 \mu \mathrm{g} / 100 \mathrm{~g}$ (pollock). There were significant differences between individuals within one species and between fish of one species from different geographical areas. For example, Atlantic cod from the North Sea had lower concentrations of iodine than cod from the Barents or Norwegian seas. It is reported that even in such developed marine countries as Norway, Finland, Iceland, England, fish an,d fish products provide only $20-30 \%$ of the daily requirement of iodine (Dahl, et al., 2004; Bath, et al., 2013; Nystrom, et al., 2016). The main products in these countries that provide the organism with iodine include dairy $-20-64 \%$ of demand and iodized salt (Rasmussen, et al., 2008; Van der Reijden, et al., 2017; Nerhus, et al., 2018).

Researchers (Nerhus, et al., 2018) indicate that in Norway, the average concentration of iodine in milk ranged from 12 to $19 \mu \mathrm{g} / 100 \mathrm{~g}$, and the concentration of iodine in eggs ranged from 23 to $43 \mu \mathrm{g} / 100 \mathrm{~g}$. In Ukraine, the average 
iodine content in milk was $9.3 \mu \mathrm{g} / 100 \mathrm{~g}$ (Mikláš, et al., 2021). In determining iodine in dairy products (Haldimann, et al., 2005) was found that the highest concentrations were in serum with a concentration of 100 to $450 \mu \mathrm{g} / 100 \mathrm{~g}$. It was also found that during cheese production, approximately $75 \%$ of iodine from milk enters the whey, about 25\% remains in the cheese (Van der Reijden, et al., 2019). At the same time, it was found that heat processing does not affect the concentration of iodine in milk (Wheeler, et al., 1983; Norouzian, et al., 2011; Soriguer, et al., 2011) whereas defatting increased the amount of iodine in milk by only $1-2 \mu \mathrm{g} / \mathrm{dm}^{3}$ (Jahreis, et al., 2007; Rasmussen, et al., 2014). In semi-hard and soft cheeses, iodine was detected in the range of $83-101 \mu \mathrm{g} / \mathrm{kg}$, in yogurt - $156-169 \mu \mathrm{g} / \mathrm{kg}$ (Haldimann, et al., 2005; FCN, 2013). However, researchers believe that the concentration of iodine in milk can reach up to $300 \mu \mathrm{g} / \mathrm{dm}^{3}$ with an additional introduction into the ratio of cows (Van der Reijden, et al., 2019). Even though dairy products supplement the human ratio with iodine, its concentration is rarely determined and is not always taken into account for the prevention of iodine deficiency.

For a long time, many countries around the world have tried to solve the problem of iodine in the daily ratio by providing the population with iodized salt containing the usual $25 \mathrm{~g}$ of potassium iodide per 1 ton of salt. However, potassium iodide $(\mathrm{KJ})$ has now been found to be unstable to light and moisture (WHO, 2007). In addition, the use of inorganic compounds $\left(\mathrm{KJ}, \mathrm{KJO}_{3}\right)$ in iodine enrichment of rations, from the point of view of the theory of functional nutrition is not perspective, because they are a chemical unnatural compound and cannot be considered a source of functional ingredients. The best way to provide the population with stable iodine is the use in iodine-deficient regions of organic iodine compounds - iodine-casein, iodine-active, "Iodis concentrate", seafood - natural sources of iodine, in particular, sea fish, mussels, shrimp, squid and, especially, brown seaweed and products of their processing (salads, jams, pasta).

One of the well-recommended products with biologically active iodine is "Iodis-concentrate" (Story, et al., 2016; Mikláś, et al., 2021). "Jodis-concentrate" is mineral artesian water with iodine, stable during storage and heat processing, recommended for use in the food industry for iodine enrichment of water, bakery products, meat, dairy, and sour-milk products (Kopchak, et al., 2017; Mikláš, et al., 2021).

Because Ukraine does not have enough functional food products that can provide consumers with the necessary level of iodine. The use of fermented milk products as a basis for the introduction of biological iodine-containing preparations is quite real and perspective. In addition, such products. as kefir is considered to be often used because, in addition to specific taste qualities, they provide the organism with useful lactic acid microflora (Kukhtyn, et al., 2018a).

Therefore, given the urgency of the problem and the literature, it is currently promising to create functional dairy products with biologically active iodine, which would allow its use for prophylactic purposes to prevent thyroid dysfunction.

The purpose of the work was to investigate changes in organoleptic, microbiological, and biochemical parameters of kefir produced with the addition of iodine during its refrigeration storage.

Scientific hypothesis. It consists of the possible production of iodized fermented milk products, which are enriched with the help of water "Iodis-concentrate".

\section{MATERIAL AND METHODOLOGY}

The work was carried out at the Ternopil Ivan Puliuj National Technical University in the laboratories of the Department of Food Biotechnology and Chemistry.

\section{Samples}

10 samples of kefir with the content of "Jodisconcentrate" were investigated - experimental samples and 5 samples of kefir were in control (without "Jodisconcentrate").

\section{Chemicals}

Kefir leaven (Good food, Italia) was used to make kefir, and Jodis-Concentrate solution (Yark-Kyiv, Ukraine) was used as a source of iodine.

Artesian mineral water "Jodis-concentrate" of the following chemical content (Table 1) (TC, 2001) was used in the experiment.

Before the conducting of the study the kefir samples had been mixed for one minute with a sterile spatula, heated in a water bath at $+37 \pm 1^{\circ} \mathrm{C}$, and prepared ten-fold dilutions according to the standard (DSTU, 2003).

Determination of the number of lactic acid microorganisms in experimental and control samples of kefir was carried out on MRS-agar medium (HiMedia, India) for this purpose, the sowings were incubated at a temperature of $37 \pm 1^{\circ} \mathrm{C}$ for 48 hours. Yeast and molds were determined on Saburo medium (HiMedia, India) at a temperature of $25 \pm 1{ }^{\circ} \mathrm{C}$ for 3-5 days. The titer of coliform bacteria was determined in Kessler medium (Pharmactive, Ukraine) incubation of crops at a temperature of $37 \pm 1{ }^{\circ} \mathrm{C}$ for 24 hours. Determination of Staphylococcus aureus in kefir was carried out on Baird-Parker agar medium (Merck KGaA, Germany).

\section{Laboratory Methods}

The titrated acidity of milk and kefir was determined by the classical titrimetric method (IS 2004). Chemically pure $\mathrm{KOH}$ was used for titration (Khimreaktiv, Ukraine).

\section{Description of the Experiment}

Sample preparation: The process of making kefir with iodine included the following technological operations: 1) assessment of quality and safety of raw materials (microbiological and physicochemical research); 2) normalization and homogenization of the mixture for fat content up to $2.5 \%$ on the laboratory homogenizer (Microtron MB 800, Kinematica, Germany); 3) pasteurization at a temperature of $80-85^{\circ} \mathrm{C}$ for $15 \mathrm{~s}$ on a mini pasteurizer (SP12, Motor Sich, Ukraine); 4) cooling to a temperature of $25 \pm 1{ }^{\circ} \mathrm{C}$, adding "Jodis concentrate" in the amount of $7.5 \mathrm{~mL}$ per 1 liter of raw material; 5) making of kefir leaven and fermentation for $6 \mathrm{~h}$ to a titratable acidity of $85-90{ }^{\circ} \mathrm{T} ; 6$ ) cooling to +4 to $+6{ }^{\circ} \mathrm{C}$; 7) packing and storage.

Number of samples analyzed: This technology was used to make 10 samples of kefir with adding of "Iodisconcentrate" and 5 samples of kefir without adding of iodine (control). Each sample was divided into 5 parts and placed in a sterile container with a lid and stored in a refrigerator at 
$+4-+6{ }^{\circ} \mathrm{C}$ for 12 days. The first part (freshly made kefir) was analyzed immediately after cooking, the second part was examined after 2 days of storage, the third - after 5 days of storage, the fourth - after 8 days, the fifth - after 12 days.

Number of experiment replication: Each portion of kefir was analyzed three times and subjected to statistical processing.

Number of experiment replication: A total of 15 samples of kefir were analyzed for microbiological, biochemical and organoleptic parame.

Statistical analysis. Statistical processing of the results was carried out using methods of variation statistics using the program Statistica 9.0 (StatSoft Inc., USA). Non-parametric methods of research were used (Wilcoxon-Mann-Whitney test). The arithmetic mean (x) and the standard error of the mean (SE) were determined. The difference between the comparable values was considered to be significant for $p<0.05$.

\section{RESULTS}

At the first stage of the research, the chemical content of "Iodis-concentrate" was analyzed (Table 1) and it was found that $1 \mathrm{~mL}$ of solution contains $40.0 \mu \mathrm{g} / \mathrm{mL}$ of iodine. That is, to ensure the minimum daily requirement of an adult for iodine (200-300 mcg recommendation) (WHO, 2007), it is necessary to consume an average of $7.5 \mathrm{~mL}$ of "Iodis concentrate". This amount was calculated and kefir was made from cow's milk so that 1 liter contained at least 300 mcg of iodine.

Organoleptic, physicochemical, and microbiological indices were determined in freshly made kefir with iodine (experimental sample) and without it (control) for compliance with the requirements of the normative document (DSTU, 2005). According to organoleptic indices, the experimental and control samples of kefir had a homogeneous, viscous, with an intact clot, a semi-liquid without gas formation, appearance and consistency, and a clean, sour-milk taste and smell. According to physicochemical indices in the experimental sample, the value of titrated and active acidity was $93.2 \pm 0.2^{\circ} \mathrm{T}$ and $\mathrm{pH}$ $4.6 \pm 0.03$ units. In the control sample, the titrated acidity was $98.0 \pm 0.2^{\circ} \mathrm{T}$ and $\mathrm{pH} 4.4 \pm 0.04$ units. The results of microbiological research are given in table 2 .

It is set (Table 2) that according to microbiological indicators freshly made samples of experimental and control kefir met the requirements provided in the standard. At the same time, it was found that the number of lactic acid bacteria in the experimental sample of kefir was 1.7 times $(p<0.05)$ less, compared with the control sample. The yeast content also in the experimental sample was 2.5 times $(p$ $<0.05$ ) less than in the control and was $2.4 \pm 0.1 \times 10^{3} \mathrm{CFU} / \mathrm{g}$ and $6.1 \pm 0.2 \times 10^{3} \mathrm{CFU} / \mathrm{g}$, in accordance.

Therefore, freshly made samples of kefir met the requirements of the standard in organoleptic, physicochemical, and microbiological indices, despite the lower titratable acidity and lower content of lactic acid bacteria and yeast in the test sample of kefir.

Further research was sent on determining the influence of added "Jodis" on the dynamics of changes in lactic acid and yeast microflora during the storage of kefir at a temperature of $+6 \pm 0.1^{\circ} \mathrm{C}$ for 12 days. The maximum allowed by the standard $\left(+6^{\circ} \mathrm{C}\right)$ storage temperature was chosen for the more intensive reproduction of microorganisms. The results of the research of changes in lactic acid bacteria in kefir during storage are shown in Figure 1.

The classical dynamics of change of lactic acid bacteria in kefir samples was revealed (Figure 1), which was characterized by gradual growth of lactic acid microorganisms during the 12-day storage period at a temperature of $+6 \pm 0.1^{\circ} \mathrm{C}$. At the same time, we observe a slowdown in the reproduction of lactic acid bacteria in the experimental sample of kefir, against the control. In particular, the number of lactic acid bacteria during the first two days of storage increased 1.3 times $(p<0.05)$ in the experimental sample and 1.5 times in a control sample of kefir.

After five days of storage, the number of lactic acid bacteria in kefir continued to increase. However, the intensity of reproduction of the microflora in the experimental sample was slightly lower than in the control sample of kefir, that is, the increase was 1.6 and 1.9 times $(p<0.05)$, in accordance, compared to the initial number.

The following definition of the number of lactic acid bacteria after 8 and 12 days of storage revealed a similar trend in the reproduction of the microflora as during the five-day studies. In particular, the number of lactobacilli after 12 days of storage in the test sample of kefir increased 2.5 times $(p<0.05)$, and in the control 3.2 times $(p<0.05)$, comparing with the amount in fresh kefir.

Data on the change of yeast in kefir containing "Jodis", compared with the control sample are shown in Figure 2.

It was found (Figure 2) that the presence of Jodis in the experimental sample of kefir influenced the intensity of yeast reproduction. In particular, during the two days of kefir storage, the amount of yeast increased on average 1.2 times in the experimental sample, against 1.3 times $(p$ $<0.05)$ in the control. That is, there is a similar regularity as for the development of lactic acid bacteria. During further storage, the reproduction rate of yeast in the control sample of kefir was on average 1.3 times $(p<0.05)$ faster $(8-12$ days), compared with yeast in the experimental sample.

Therefore, the research indicates that "Jodis" added to the milk mixture for the production of kefir inhibits the development of lactic acid and yeast microflora in the product during storage.

The results of the research of the change in titratable acidity in kefir samples during storage are shown in Figure 3.

The results (Figure 3) indicate that the growth curve of the values of the titrated acidity had a regularity to the fastest increase in the control sample of kefir. In particular, during eight days of storage, the titrated acidity in the control sample of kefir increased 1.5 times $(p<0.05)$ and was 142.9 $\pm 0.3^{\circ} \mathrm{T}$. This value of titrated acidity by $12.9^{\circ} \mathrm{T}$ exceeded the permissible level $\left(130^{\circ} \mathrm{T}\right)$, which is normalized by the standard (DSTU, 2005). At the same time, in the experimental sample of kefir with "Jodis" the value of titrated acidity reached the level of $130^{\circ} \mathrm{T}$ on the 12 th day of storage.

Thus, in kefir with "Jodis" the dynamics of enzymatic processes were slower compared to the control sample. This gives reason to believe that it can be stored for a longer period without violating the requirements of the standard in terms of titrated acidity of the product. 


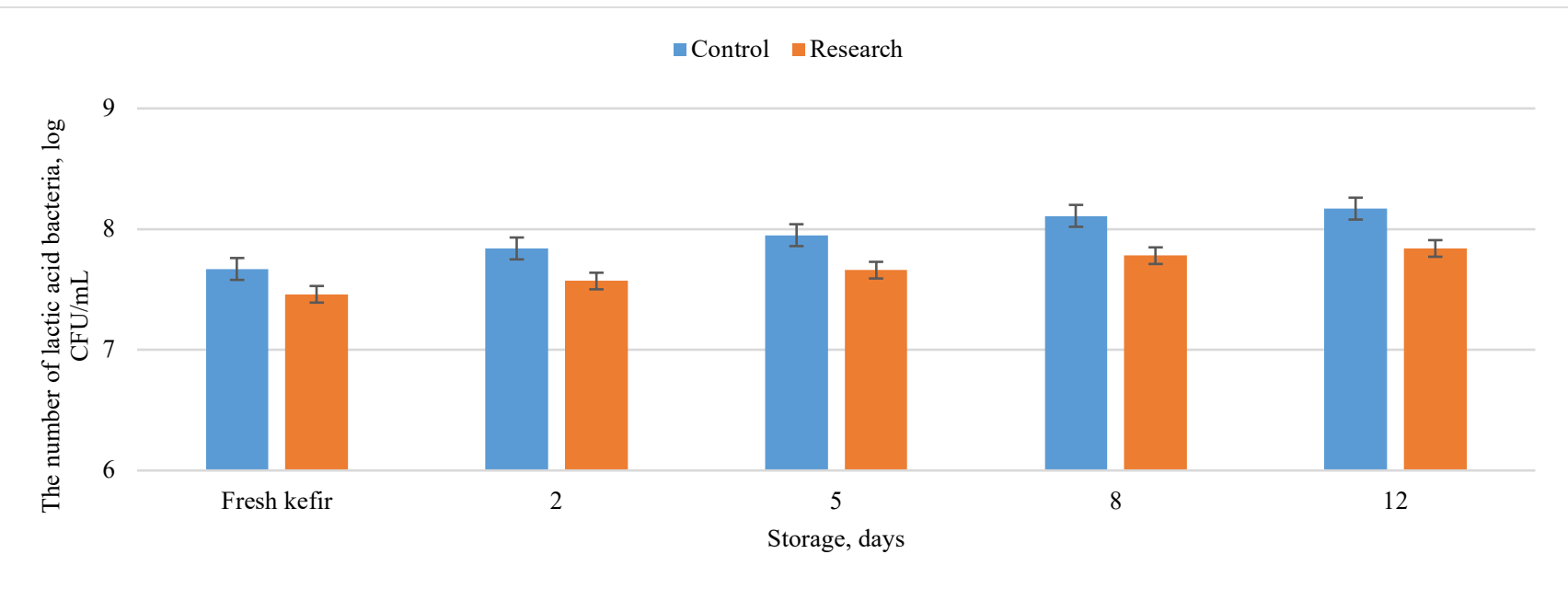

Figure 1 Dynamics of changes in the number of lactic acid bacteria in kefir containing "Iodis" during storage at a temperature of $+6 \pm 0.1^{\circ} \mathrm{C}$.

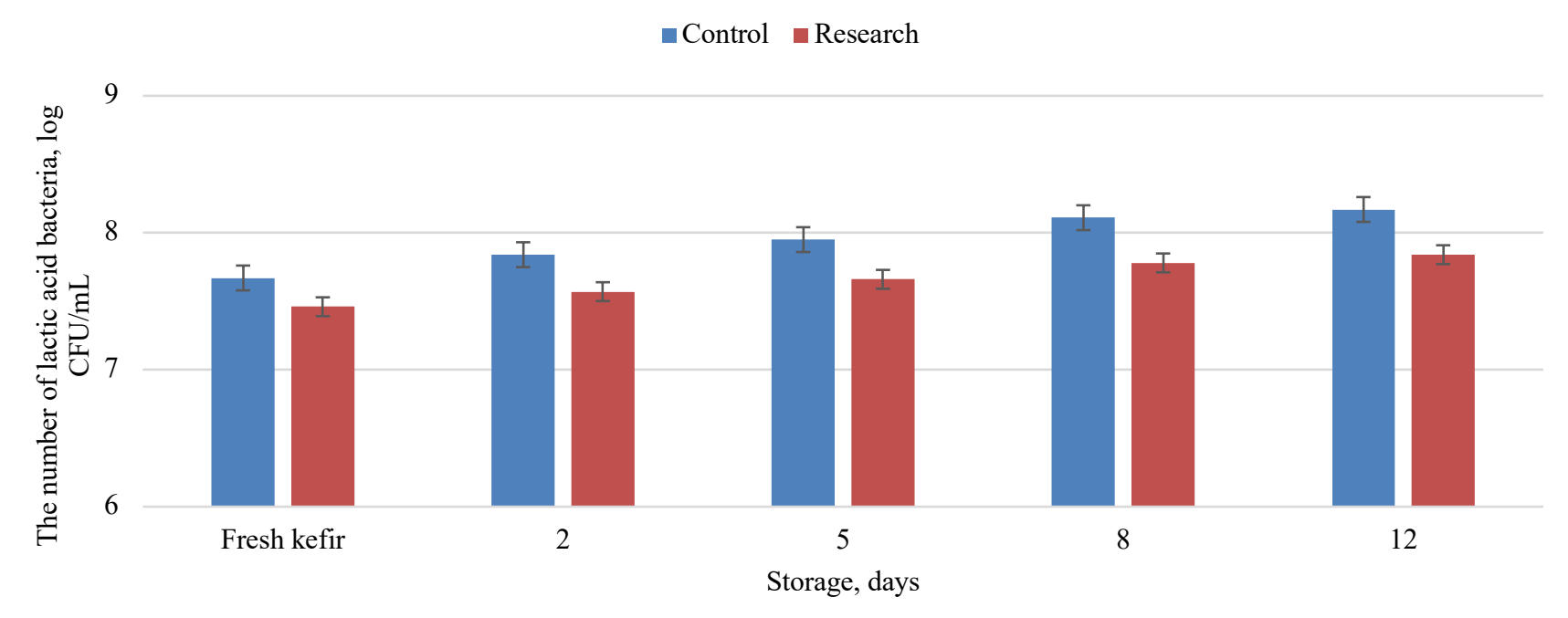

Figure 2 Dynamics of change in the amount of yeast in kefir containing "Jodis" during storage at a temperature of $+6 \pm 0.1^{\circ} \mathrm{C}$.

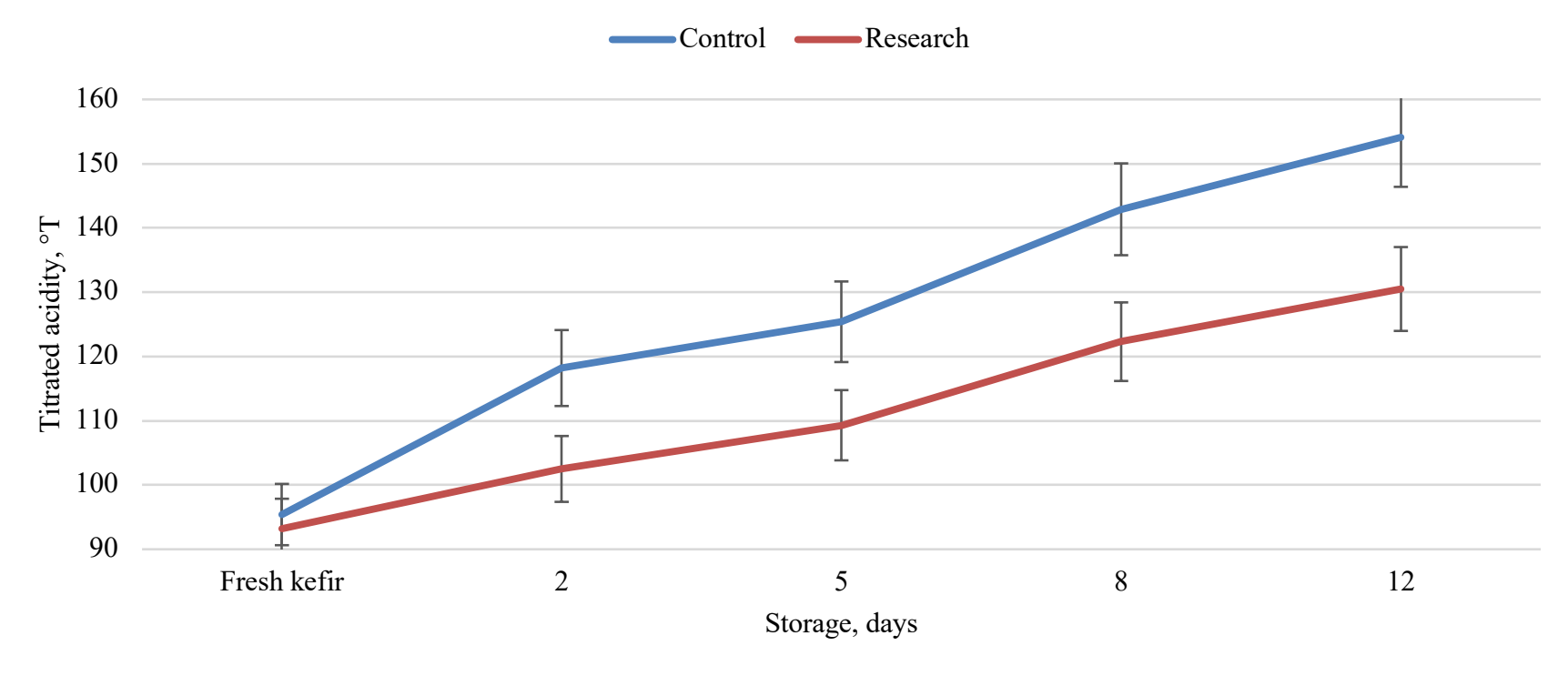

Figure 3 Dynamics of change of titrated acidity in kefir with the content of "Jodis" during storage at a temperature of $+6 \pm 0.1^{\circ} \mathrm{C}$. 
Table 1 Chemical composition of "Jodis concentrate".

\begin{tabular}{lc}
\hline \multicolumn{1}{c}{ Indicators } & Number \\
\hline Total mineralization, $\mathrm{g} / \mathrm{dm}^{3}$ & $0.4-0.8$ \\
Sodium + Potassium, $\mathrm{mg} / \mathrm{dm}^{3}$ & $10-100$ \\
Calcium, $\mathrm{mg} / \mathrm{dm}^{3}$ & $50-150$ \\
Magnesium, $\mathrm{mg} / \mathrm{dm}^{3}$ & $10-100$ \\
Chlorides, $\mathrm{mg} / \mathrm{dm}^{3}$ & $<50$ \\
Sulfates, $\mathrm{mg} / \mathrm{dm}^{3}$ & $<50$ \\
Hydrocarbonates, $\mathrm{mg} / \mathrm{dm}^{3}$ & $300-600$ \\
Iodine, $\mu \mathrm{g} / \mathrm{cm}^{3}$ & 40.0 \\
Organic matter content, $\mathrm{mg} / \mathrm{dm}^{3}$ & $<30$ \\
\hline
\end{tabular}

Table 2 Microbiological indices of freshly made experimental and control samples of kefir.

\begin{tabular}{lccc}
\hline \multicolumn{1}{c}{ Indicator } & $\begin{array}{c}\text { Search sample - kefir } \\
\text { with iodine }\end{array}$ & $\begin{array}{c}\text { Control - kefir } \\
\text { The number of lactic acid } \\
\text { microorganisms, CFU/g }\end{array}$ & $\begin{array}{c}\text { Permissible quantity according to } \\
\text { DSTU 4417:2005 }\end{array}$ \\
$\begin{array}{l}\text { Yeast, CFU/g } \\
\text { The titer of coliform bacteria, g }\end{array}$ & $2.8 \pm 0.2 \times 10^{7}$ & $4.7 \pm 0.2 \times 10^{7}$ & No less $1 \times 10^{7}$ \\
Molds, CFU/g & $>1$ & $6.1 \pm 0.2 \times 10^{3}$ & No less $1 \times 10^{3}$ \\
Staphylococcus aureus, g & $8.3 \pm 0.3$ & $>1$ & Is not allowed 0,01 \\
Salmonella spp., $25 \mathrm{~g}$ & $>1$ & $>1.1 \pm 0.3$ & Not more 50 \\
\hline
\end{tabular}

Table 3 Scale for organoleptic evaluation of kefir with "Jodis".

\begin{tabular}{|c|c|c|}
\hline The name of the indicator & Characteristics of the indicator & $\begin{array}{l}\text { Evaluation } \\
\text { in points }\end{array}$ \\
\hline \multirow{5}{*}{ Taste and smell (5 points) } & Pure, sour milk. Taste without extraneous tastes and smells & 5 \\
\hline & Pure, sour milk. The taste is pungent, without foreign tastes and odors & 4 \\
\hline & $\begin{array}{l}\text { Sour milk. The taste is excessively pungent, without extraneous flavors and } \\
\text { odors }\end{array}$ & 3 \\
\hline & Excessively sour milk (sour) & 2 \\
\hline & Unexpressed taste or presence of extraneous flavors & 1 \\
\hline \multirow{5}{*}{$\begin{array}{l}\text { Appearance and } \\
\text { consistency ( } 5 \text { points })\end{array}$} & Homogeneous, viscous, with intact clot, semi-liquid, without gas formation & 5 \\
\hline & $\begin{array}{l}\text { Homogeneous, viscous, with intact clot, with slight serum separation, semi- } \\
\text { liquid, without gas formation }\end{array}$ & 4 \\
\hline & $\begin{array}{l}\text { Homogeneous, viscous, with some broken clot, with slight serum separation, } \\
\text { semi-liquid, with some gas formation }\end{array}$ & 3 \\
\hline & $\begin{array}{l}\text { Homogeneous, with a broken clot and serum separation, liquid, with gas } \\
\text { formation }\end{array}$ & 2 \\
\hline & Homogeneous, with significant serum separation, liquid, with gas formation & 1 \\
\hline Color & Milky white, uniform throughout the mass & 2 \\
\hline (2 points) & Milk white, not uniform for the whole mass & 1 \\
\hline $\begin{array}{l}\text { General perception } \\
(3 \text { points })\end{array}$ & The harmonious combination of taste and smell & 3 \\
\hline Overall maximum score & & 15 \\
\hline
\end{tabular}




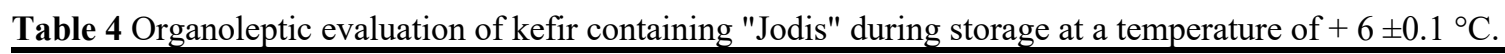

\begin{tabular}{|c|c|c|c|c|c|c|}
\hline \multirow[t]{2}{*}{ Product sample } & \multirow[t]{2}{*}{ Indicators } & \multicolumn{5}{|c|}{ Storage for, days } \\
\hline & & fresh yogurt & 2 & 5 & 8 & 12 \\
\hline \multirow{5}{*}{$\begin{array}{l}\text { Experimental } \\
\text { kefir with } \\
\text { "Jodis" }\end{array}$} & Taste and smell (5) & 5.0 & 5.0 & 4.8 & 4.6 & 4.4 \\
\hline & $\begin{array}{l}\text { Appearance and } \\
\text { consistency }(5)\end{array}$ & 5.0 & 5.0 & 5.0 & 5.0 & 5.0 \\
\hline & Color (2) & 2.0 & 2.0 & 2.0 & 2.0 & 2.0 \\
\hline & $\begin{array}{l}\text { General perception } \\
\text { (3) }\end{array}$ & 3.0 & 3.0 & 3.0 & 2.8 & 2.8 \\
\hline & $\begin{array}{c}\text { The total number of } \\
\text { points }(15)\end{array}$ & 15.0 & 5.0 & 14.8 & 14.4 & 14.2 \\
\hline \multirow{5}{*}{ Control (kefir) } & Taste and smell (5) & 5.0 & 5.0 & 4.6 & 4.2 & 4.0 \\
\hline & $\begin{array}{l}\text { Appearance and } \\
\text { consistency }(5)\end{array}$ & 5.0 & 5.0 & 5.0 & 5.0 & 4.8 \\
\hline & Color (2) & 2.0 & 2.0 & 2.0 & 2.0 & 2.0 \\
\hline & $\begin{array}{l}\text { General perception } \\
\text { (3) }\end{array}$ & 3.0 & 3.0 & 3.0 & 2.8 & 2.8 \\
\hline & Total Points (15) & 15 & 15.0 & 14.4 & 14.0 & 13.6 \\
\hline
\end{tabular}

It is known that the organoleptic properties of fermented milk products primarily depend on the quality of milk raw materials which undergo fermentation, introduced food additives, and the activity of fermentation crops. Therefore, the next part of the work was to conduct an organoleptic evaluation of kefir samples. However, before the tasting, a scale was developed to evaluate kefir samples (Table 3).

The scale for evaluating test samples of yogurt included the determination of taste and smell, which was evaluated with a maximum of 5 points; appearance and consistency 5 points; color was evaluated at 2 points and general perception -3 points.

According to the results of the tasting commission of kefir samples (Table 5), it was found that the shelf life of the product deteriorates its organoleptic properties. The decrease in the overall score of the experimental and control sample of kefir is mainly due to a defect in taste, in particular the appearance of a pungent sour-milk taste, which develops due to lactic acid fermentation. No exterior taste or odor was detected in the research sample. At the same time, in the research sample of kefir, a decrease in the total score by 0.2 points, compared with the initial amount was observed on the 5th day of storage. At the same time, in the control sample for this storage period, the decrease was 0.6 points. On the 12 th day of kefir storage, the difference between the experimental and control samples was 0.6 points, with an overall score of 14.2 and 13.6 points, respectively.

Thus, the addition of $7.5 \mathrm{~mL}$ of "Iodis concentrate" per 1 liter of milk mixture for fermentation of kefir does not reduce the organoleptic characteristics of the produced product. In this case, kefir containing iodide had better organoleptic characteristics during 12 days of storage, compared with the control sample.

\section{DISCUSSION}

Iodine is a trace element whose daily requirement ranges from 100 to $300 \mu \mathrm{g} /$ day, depending on age (Hynes et al., 2013; Abel et al., 2017; Walther et al., 2018). Many countries, including Ukraine, are in the zone of endemic iodine deficiency (Dahl et al., 2004; Bath et al., 2013; Nystrom et al., 2016; Ahvanooei, et al., 2021). Unfortunately, in Ukraine, there is a lack of food that can provide the organism with the required amount of iodine (Ryzhkova et al., 2017; Kopchak and Pokotylo, 2018b). On the other hand, dairy products are a good basis for the production of many functional products (Dal Bello et al., 2017; Kukhtyn et al., 2021; Albracht-Schulte et al., 2018; Yukalo et al., 2019; Lialyk et al., 2020). This research shows that the problem of iodine deficiency can be solved by producing high-quality kefir enriched with biological iodine - a solution of "Iodis-concentrate". In particular, it was found that freshly made kefir with iodide in organoleptic, physicochemical, and microbiological indicators met the requirements of the standard (DSTU, 2005), despite $2.3^{\circ} \mathrm{T}$ lower titratable acidity and 1.7 times lower content of lactic acid bacteria than in the control sample of kefir.

During the storage of samples of kefir with Jodis, a slowdown in the reproduction of lactic acid bacteria was detected compared to the control sample. In particular, the number of lactic acid bacteria during the first two days of storage increased 1.3 times in the experimental sample and 1.5 times in the control sample of kefir. After 12 days of storage, the number of lactobacilli in the test sample of kefir increased 2.5 times, and in the control 3.2 times, compared with the amount in fresh kefir. Analogical patterns were observed in determining the development of yeast. In particular, the rate of reproduction of yeast in the control sample of kefir was, on average, 1.3 times faster $(8-12$ days), comparing with yeast in the experimental sample. This gives reason to consider that "Jodis" added to the milk mixture for the production of kefir inhibits the development 
of lactic acid and yeast microflora during production technology and in the finished product during its storage. The presence of antibacterial action in iodine concentrate has been reported by other researchers (Mikláš, et al., 2021). Despite the influence of added Jodis concentrate on the development of microflora in the technology of production and storage of kefir, the researchers (TC, 2001; Mikláś, et al., 2021) report that overdose and negative action on consumers from this preparation is not possible. It was also found that during the 12-day storage period at a temperature of $+6{ }^{\circ} \mathrm{C}$, the titrated acidity in kefir with iodine increased 1.4 times, and in the control 1.6 times and was $130.5^{\circ} \mathrm{T}$ and $154.1^{\circ} \mathrm{T}$, respectively. For such values of acidity, the test sample of kefir still met the requirements of the standard (DSTU, 2005), and the control was $24.1^{\circ} \mathrm{T}$ higher. In general, we can confirm that in this case, iodine in kefir acts in part as a biological preservative, due to which it is extended the expiration date of the product. Thus kefir with iodine on organoleptic indicators exceeded 0.6 points of the test sample, generally because of less sour taste. Thus, we agree with the data of researchers (Haldimann, et al., 2005; Rasmussen, et al., 2008; Norouzian et al., 2011; Nerhus et al., 2018; Van der Reijden, et al., 2019), who recommend increasing the concentration of iodine in dairy products by introducing iodine into the ration of cows or immersion of teats in iodine-containing drugs (Reijden et al., 2017; Walther et al., 2018; Ahvanooei, et al., 2021). At the same time, we consider that the priority direction of overcoming iodine deficiency is the production of traditional fermented milk products enriched with biological iodine from natural sources. It is Jodis concentrate that belongs to such food additives (Stori, et al., 2016; Kopchak \& Pokotylo, 2018b; Mikláš, et al., 2021).

\section{CONCLUSION}

It was found that freshly produced kefir with iodide in organoleptic, physicochemical, and microbiological indicators met the requirements of the standard, despite 2.3 ${ }^{\circ} \mathrm{T}$ lower titratable acidity and 1.7 times lower content of lactic acid bacteria than in the control sample of kefir.

Therefore, the produced kefir with the addition of iodine was characterized by good microbiological, biochemical indicators, and organoleptic properties and can be considered a functional product to normalize the intake of stable iodine.

\section{REFERENCES}

Abel, M. H., Caspersen, I. H., Meltzer, H. M., Haugen, M., Brandlistuen, R. E., Aase, H., Brantsæter, A. L. 2017. Suboptimal maternal iodine intake is associated with impaired child neurodevelopment at 3 years of age in the Norwegian Mother and Child Cohort Study. The Journal of nutrition, vol. 147, no. 7, p. 1314-1324. https://doi.org/10.3945/jn.117.250456

Ahvanooei, M. R. R., Norouzian, M. A., Hedayati, M., Vahmani, P. 2021. Effect of potassium iodide supplementation and teat-dipping on iodine status in dairy cows and milk iodine levels. Domestic Animal Endocrinology, vol. 74, p. 106504. https://doi.org/10.1016/j.domaniend.2020.106504

Albracht-Schulte, K., Kalupahana, N. S., Ramalingam, L., Wang, S., Rahman, S. M., Robert-McComb, J., MoustaidMoussa, N. 2018. Omega-3 fatty acids in obesity and metabolic syndrome: a mechanistic update. The Journal of nutritional biochemistry,

$$
\text { vol. }
$$

58 p.

https://doi.org/10.1016/i.jnutbio.2018.02.012

Bath, S. C., Rayman, M. P. 2013. Iodine deficiency in the U.K.: an overlooked cause of impaired neurodevelopment? Proceedings of the Nutrition Society, vol. 72, no. 2, p. 226-235. https://doi.org/10.1017/S0029665113001006

Dahl, L., Johansson, L., Julshamn, K., Meltzer, H. M. 2004. The iodine content of Norwegian foods and diets. Public Health Nutrition, vol. 7, no. 4, p. 569-576. https://doi.org/10.1079/PHN2003554

Dal Bello, B., Torri, L., Piochi, M., Bertolino, M., Zeppa, G. 2017. Fresh cheese as a vehicle for polyunsaturated fatty acids integration: effect on physico-chemical, microbiological and sensory characteristics. International journal of food sciences and nutrition, vol. 68, no. 7, p. 800-810. https://doi.org/10.1080/09637486.2017.1301891

DSTU, 2003. DSTU IDF 122C:2003. Milk and dairy products. Preparation of samples and dilutions for microbiological research. National Standard of Ukraine.

DSTU, 2005. DSTU 4417:2005. Kefir. Specifications. National Standard of Ukraine.

Federal Commission for Nutrition, 2013. Iodine Supply in Switzerland: Current Status and Recommendations. Expert Report of the FCN. Zurich: Federal Office of Public Health.

Haldimann, M., Alt, A., Blanc, A., Blondeau, K. 2005. Iodine content of food groups. Journal of Food Composition and Analysis, vol. 18, no. 6, p. 461-471. https://doi.org/10.1016/j.jfca.2004.06.003

Hynes, K. L., Otahal, P., Hay, I., Burgess, J. R. 2013. Mild iodine deficiency during pregnancy is associated with reduced educational outcomes in the offspring: 9-year follow-up of the gestational iodine cohort. Journal of Clinical Endocrinology \& Metabolism, vol. 98, no. 5, p. 1954-1962. https://doi.org/10.1210/jc.2012-4249

IS, 2004. Interstate standard 3624-92. Milk and milk products.Titrimetric methods of acidity determination.

Jahreis, G., Leiterer, M., Fechner, A. 2007. Jodmangelprophylaxe durch richtige Ernährung. Prävention und Gesundheitsförderung, vol. 2, no. 3, p. 179-184. https://doi.org/10.1007/s11553-007-0068-y

Kopchak, N. H., Pokotylo, O. S. 2018b. Age-specific features of fatty acid composition of lipid serum in rats with obesity under the influence of iodine. Medical and Clinical Chemistry, vol. 3, no. 20, p. 63-69. https://doi.org/10.11603/mcch.2410681X.2018.v0.i3.9567

Kopchak, N. H., Pokotylo, O. S., Kukhtyn, M. D., Yaroshenko, T. Y., Kulitska, M. I., Bandas, I. A. 2018a. Age and sex characteristics of thyroxine and triiodothyronine content in the blood of white rats with experimental alimentary obesity under the influence of iodine. Research Journal of Pharmaceutical, Biological and Chemical Sciences, vol. 9, no. 5, p. 2392-2397.

Kopchak, N. H., Pokotylo, O. S., Kukhtyn, M. D., Koval, M. I. 2017. Influence of iodine on the indicators of lipid profile of rats blood of different age in experimental obesity. Medicinal and clinical chemistry, vol. 19, no. 4, p. 123-128. https://doi.org/10.11603/mcch.2410-681X.2017.v0.i4.8437

Kukhtyn, M., Salata, V., Horiuk, Y., Kovalenko, V., Ulko, L., Prosyanyi S., Shuplyk, V., Kornienko, L. 2021. The influence of the denitrifying strain of Staphylococcus carnosus No. 5304 on the content of nitrates in the technology of yogurt production. Potravinarstvo Slovak Journal of Food Sciences, vol. 15, p. 66-73. https://doi.org/10.5219/1492

Kukhtyn, M., Vichk, O., Horyuk, Y., Shved, O., Novikov, V. 2018a. Some probiotic characteristics of a fermented milk product based on microbiota of "Tibetan kefir grains" 
cultivated in Ukrainian household. Journal of Food Science and Technology, vol. 55, no. 1, p. 252-257. https://doi.org/10.1007/s13197-017-2931-y

Kukhtyn, M., Vichko, O., Kravets, O., Karpyk, H., Shved, O., Novikov, V. 2018b. Biochemical and microbiological changes during fermentation and storage of a fermented milk product prepared with Tibetan Kefir Starter. Archivos Latinoamericanos de Nutricion, vol. 68, no. 4, p. 1-6.

Lialyk, A., Pokotylo, O., Kukhtyn, M., Beyko, L., Horiuk, Y., Dobrovolska, S., Mazur, O. 2020. Fatty acid composition of curd spread with different flax oil content. Nova Biotechnologica et Chimica, vol. 19, no. 2, p. 216-222. https://doi.org/10.36547/nbc.v19i2.776

Mikláš, Š., Tančin, V., Toman, R., \& Trávníček, J. 2021. Iodine concentration in milk and human nutrition: A review. Czech Journal of Animal Science, vol. 66, no. 6, p. 189-199. https://doi.org/10.17221/167/2020-CJAS

Nerhus, I., Wik Markhus, M., Nilsen, B. M., Øyen, J., Maage, A., Ødegård, E. R., Midtbø, L. K., Frantzen. S., Kögel, T., Graff, I. E., Lie, Ø., Dahl, L., Kjellevold, M. 2018. Iodine content of six fish species, Norwegian dairy products and hen's egg. Food \& Nutrition Research, vol. 62, p. 1-13. https://doi.org/10.29219/fnr.v62.1291

Norouzian, M. A. 2011. Iodine in raw and pasteurized milk of dairy cows fed different amounts of potassium iodide. Biological Trace Element Research, vol. 139, p. 160-167. https://doi.org/10.1007/s12011-010-8651-z

Nystrom, H. F., Brantsaeter, A. L., Erlund, I., Gunnarsdottir, I., Hulthen, L., Laurberg, P., Meltzer, H. M. 2016. Iodine status in the Nordic countries - past and present. Food \& Nutrition Research, vol. $60, \quad$ p. $\quad 1-15$. https://doi.org/10.3402/fnr.v60.31969

Rasmussen, L. B., Carle, A., Jorgensen, T., Knudsen, N., Laurberg, P., Pedersen, I. B., Ovesen, L. 2008. Iodine intake before and after mandatory iodization in Denmark: results from the Danish Investigation of Iodine. Intake and Thyroid Diseases (DanThyr) study. British Journal of Nutrition, vol. 100, no. $1, \quad$ p. $166-173$. https://doi.org/10.1017/S0007114507886387

Rasmussen, L. B., Carlé, A., Jørgensen, T., Knuthsen, P., Krejbjerg, A., Perrild, H., Ovesen, L. 2014. Iodine excretion has decreased in Denmark between 2004 and 2010-the importance of iodine content in milk. British Journal of Nutrition, vol. 112, no. 12, p. 1993-2001. https://doi.org/10.1017/S0007114514003225

Reijden, O. L., Zimmermann, M. B., Galetti, V. 2017. Iodine in dairy milk: Sources, concen- trations and importance to human health. Best Pract. Res. Clin. Endocrinol. Metabs., vol. 31, 385-395. https://doi.org/10.1016/j.beem.2017.10.004

Ryzhkova, T., Bondarenko, T., Dyukareva, G., Biletskaya, Y. 2017. Development of a technology with an iodinecontaining additive to produce kefir from goat milk. EassternEuropean Journal of Enterprise Technologies, vol. 3/11, no. 87, p. 37-44. https://doi.org/10.15587/1729-4061.2017.103824

Soriguer, F., Gutierrez-Repiso, C., Gonzalez-Romero, S., Olveira, G., Garriga, M. J., Velasco, I., Endocrinology, S. 2011. Iodine concentration in cow's milk and its relation with urinary iodine concentrations in the population. Clinical Nutrition, vol. 30, no. 1, p. 44-48. https://doi.org/10.1016/j.clnu.2010.07.001

Stroi, O. A., Slipachuk, L. V., Kazakova L. M. 2016. The Study of Iodine Status among Schoolchildren from Kyiv and Ways to Correct the Revealed Violations. Clinical Pediatrics, vol. 5, no. 73, p. 72-75. https://doi.org/10.22141/2224$\underline{0551.5 .73 .2016 .78304}$
TC (Technical conditions) 14326060.003-98. Raw materials for production of iodized products "Iodis concentrate", 2001, $1-15$.

Van der Reijden, O. L., Galetti, V., Herter-Aeberli, I., Zimmermann, M. B., Zeder, C., Krzystek, A., Schlegel, P. 2019. Effects of feed iodine concentrations and milk processing on iodine concentrations of cows' milk and dairy products, and potential impact on iodine intake in Swiss adults. British Journal of Nutrition, vol. 122, no. 2, p. 172-185. https://doi.org/10.1017/S0007114519001041

Van der Reijden, O. L., Zimmermann, M. B., Galetti, V. 2017. Iodine in dairy milk: Sources, concentrations and importance to human health. Best Practice \& Research Clinical Endocrinology \& Metabolism, vol. 31, no. 4, p. 385395. https://doi.org/10.1016/j.beem.2017.10.004

Walther, B., Wechsler, D., Schlegel, P., Haldimann, M. 2018. Iodine in Swiss milk depending on production (conventional versus organic) and on processing (raw versus UHT) and the contribution of milk to the human iodine supply. Journal of Trace Elements in Medicine and Biology: Organ of the Society for Minerals and Trace Elements (GMS), vol. 46, p. 138-143. https://doi.org/10.1016/j.jtemb.2017.12.004

Wheeler, S. M., Fleet, G. H., Ashley, R. J. 1983. Effect of processing upon concentration and distribution of natural and iodophor-derived iodine in milk. Journal of Dairy Science, vol. 66 , p. 187-195. https://doi.org/10.3168/jds.S00220302(83)81776-7

WHO, UNICEF and ICCIDD, 2007. Assessment of iodine deficiency disorders and monitoring their elimination. 3rd ed. Geneva, Switzerland: WHO, 2007.

Yukalo, V., Datsyshyn, K., Storozh, L. 2019. Comparison of products of whey proteins concentrate proteolysis, obtained by different proteolytic preparations. Eastern-European Journal of Enterprise Technologies, vol. 5, no. 11-101, p. 40-47. https://doi.org/10.15587/1729-4061.2019.177314

\section{Contact address:}

Diana Dalevska, Ternopil Ivan Pului National Technical University, Faculty of Engineering of Machines, Structures and Technologies, Department of Food Biotechnology and Chemistry, Ruska, 56, 46001, Ternopil, Ukraine, Tel.: +380972110257,

E-mail: dalievska.d@gmail.com

ORCID: https://orcid.org/0000-0003-0578-9971

Oleg Pokotylo, Ternopil Ivan Pului National Technical University, Faculty of Engineering of Machines, Structures and Technologies, Department of Food Biotechnology and Chemistry, Ruska, 56, 46001, Ternopil, Ukraine, Tel.: +380972079605

E-mail: pokotylo oleg@ukr.net

ORCID: https://orcid.org/0000-0001-8693-8240

Mykola Kukhtyn, Ternopil Ivan Pului National Technical University, Faculty of Engineering of Machines, Structures and Technologies, Department of Food Biotechnology and Chemistry, Ruska, 56, 46001, Ternopil, Ukraine, Tel.: $+380972392057$

E-mail: kuchtynnic@gmail.com

ORCID: https://orcid.org/0000-0002-0195-0767

Nataliia Kopchak, Ternopil Ivan Pului National Technical University, Faculty of Engineering of Machines, Structures and Technologies, Department of Food Biotechnology and Chemistry, Ruska, 56, 46001, Ternopil, Ukraine, Tel.: +380968514522 ,

E-mail: kurpsak1@gmail.com

ORCID: https://orcid.org/0000-0002-4094-0203 
Volodymyr Salata, Lviv National University of Veterinary Medicine and Biotechnologies named after S. Z. Gzhytskyj, Faculty of Veterinary Hygiene, Ecology and Law, Department of Veterinary-Sanitary Inspection, Pekarska, 50, 79010, Lviv, Ukraine, Tel.: +380677288933,

E-mail: salatavolod@ukr.net

ORCID: https://orcid.org/0000-0002-7175-493

*Yulia Horiuk, State Agrarian and Engineering University in Podilya, Faculty of Veterinary Medicine and Technologies in Livestock, Department of Infectious and Parasitic Diseases, Schevchenko, 13, 32301, KamianetsPodilskyi, Ukraine, Tel.: +380976617964,

E-mail: goruky@,ukr.net

ORCID: https://orcid.org/0000-0002-7162-8992
Tetyana Uglyar, I. Horbachevsky Ternopil National Medical University, Department of Oncology, Radiation Diagnostics and Therapy and Radiation Medicine Food Biotechnology and Chemistry, Freedom Square, 1, 46001, Ternopil, Ukraine, Tel.: +380972079602, E-mail: tan44a@ukr.net

ORCID: https://orcid.org/0000-0001-8147-730X

Corresponding author: * 